ТИТОВА О.В., ДЯКУНОВСБКИЙ О.є.

\title{
ПРАВОВИЙ СТАТУС ПРОСТОГО АКЦІОНЕРНОГО ТОВАРИСТВА В РЕСПУБЛІЩ ПОЛЬЩА
}

У статті зазначено основні нормативно-правові акти Республіки Польща, які визначають порядок створення, діяльності та ліквідації торгівельних товариств, види товариств. Наведено поділ торгових товариств на дві групи: особові та капітальні товариства. Наголошено на тому, що законодавче регулювання видів торгових товариств у Республіці Польща $є$ незмінним протягом тривалого часу. Нещодавно до Кодексу торгових товариств Республіки Польща було внесено зміни, впроваджено нову організаційно-правову форму суб'єкта підприємницької діяльності - просте акціонерне товариство. Норми Кодексу торгових товариств Республіки Польща щодо простого акціонерного товариства мають набути чинності з 01 березня 2020 року.

У статті зазначено основні мотиви та економічне обгрунтування, якими керувався польський законодавець, запроваджуючи новий вид торгового товариства у національній системі законодавства. Вказано, що не всі організаційно-правові форми, які існують у Республіці Польща, повністю можуть забезпечити потреби суб'єктів підприємницької діяльності, особливо тих, які мають намір реалізувати StartUp або здійснювати діяльність у сфері нових технологій.

Зроблено висновок про те, що просте акціонерне товариство $є$ товариством, у якому поєднано найбільш позитивні ознаки та елементи товариства з обмеженою відповідальністю та акціонерного товариства. Зазначено основні особливості простого акціонерного товариства: відсутність бар'єрів для створення товариства; швидка процедура електронної реєстрації; спрощення та діджиталізація процедури управління товариством; свобода та гнучкість у визначенні видів акцій та принципів діяльності товариства; просте управління активами товариства; спрощений електронний реєстр акціонерів, можливість використання блокчейну для ведення реєстру акціонерів; відсутність статусу публічного товариства; гнучка структура органів управління; спрощена процедура ліквідації товариства.

Вказано про неможливість пристосування існуючих організаційно-правових форм суб'єктів підприємництва в Україні до потреб, які виникають в сучасній економіці. Запропоновано вивчати досвід Республіки Польща щодо функціонування простого акціонерного товариства з метою використання позитивного досвіду, особливо в частині можливості запровадження нових організаційно-правових форм суб'єктів підприємництва, а також застосування блокчейну для ведення реєстру акціонерів у товаристві, діджиталізації процедури управління товариством, спрощення та пришвидшення процедури ліквідації товариства у законодавство України.

Ключові слова: організаційно-правова форма, суб'єкт підприємницької діяльності, Кодекс торгових товариств Республіки Польща, StartUp, блокчейн, реєстр акціонерів, діджиталізація.

( ) ТИТОВА О.В. - кандидат юридичних наук, доцент, доцент кафедри господарського права (Донецький національний університет імені Василя Стуса)

(C) ДЯКУНОВСЬКИЙ О.С. - аспірант кафедри господарського права (Донецький національний університет імені Василя Стуса) 
The article describes the main normative legal acts of the Republic of Poland, which determine the procedure of creation, activity and liquidation of trading companies, types of companies. There is a division of trading companies into two groups: personal and capital companies. It is emphasized that the legislative regulation of types of trading companies in the Republic of Poland has been unchanged for a long time. Recently, the Code of Commerce of the Republic of Poland was amended, and a new organizational and legal form of a business entity - a simple joint stock company - was introduced.

The rules of the Commercial Code of the Republic of Poland regarding a joint stock company are to enter into force on March 1, 2020. The article outlines the main motives and economic rationale that led the Polish legislator to introduce a new type of trading company in the national system of legislation. It is stated that not all legal forms that exist in the Republic of Poland are fully able to meet the needs of business entities, especially those that intend to implement StartUp or to carry out activities in the field of new technologies. It is concluded that a simple joint-stock company is a company that combines the most positive features and elements of a limited liability company and a joint-stock company.

The main features of a simple joint-stock company are indicated, such as: absence of barriers to formation of the company; fast electronic registration procedure; simplification and digitization of the company management procedure; freedom and flexibility in defining types of shares and principles of company activity; easy management of company assets; a simplified electronic shareholder register, the ability to use a blockchain to maintain a shareholder register; lack of status of public company; flexible structure of management bodies; simplified procedure for liquidation of the company.

It is pointed out that it is impossible to adapt the existing legal forms of business entities in Ukraine to the needs that arise in the modern economy. It is suggested to study the experience of the Republic of Poland on the functioning of a simple joint-stock company in order to use the positive experience, especially regarding the possibility of introducing new organizational and legal forms of business entities, as well as the use of blockchain to maintain a register of shareholders in the company, simplify the procedure of managing the company, simplify and expediting the procedure of liquidation of the company, into the legislation of Ukraine.

Key words: legal form, business entity, the Code of Commercial companies of the Republic of Poland, StartUp, blockchain, register of shareholders, digitization.

Вступ. Успішне функціонування підприємництва залежить від багатьох факторів, в тому числі і від вдалого вибору суб'єктом підприємницької діяльності організаційно-правової форми. Існуючий широкий спектр організаційно-правових форм господарських товариств $\epsilon$ не результатом випадку, а зумовлений зміщенням акцентів у вимаганні виконання певних функцій цим правовим інститутом на кожному етапі його розвитку, а також виникненням, розвитком і співіснуванням у рамках національних економічних систем різних укладів - індивідуально-сімейного, державного, приватно-ринкового та громадсько-цивільного, наявних економіці ринкового типу [1, с. 112].

Юридична особа як учасник цивільних правовідносин «живе» за певними законами, постійно удосконалюючись у зв'язку зі зміною соціально-економічних формацій. Це відбивається i на тих організаційно-правових формах, в яких вона може функціонувати в сучасних умовах [2, с. 93]. 3 цієї позиції дослідження проблематики організаційно-правових форм комерційних товариств, у тому числі в аспекті зарубіжного досвіду, є актуальним як із теоретичної, так і з практичної точки зору.

Аналіз останніх досліджень. Проблематика організаційно-правових форм господарських товариств у контексті розвитку економічних відносин має об'єктивні причини та постійно привертає увагу вчених і дослідників багатьох галузей права. Їй присвячено численні наукові праці дослідників О. Вінник, В. Борисової, Д. Задихайла, І. Кучеренко, К. Кочергіної, О. Кібенко, І. Коваль, Н. Саніахметової, Р. Гейнц та інших. Різні питання корпоративного права Республіки Польща були предметом наукових інтересів I. Яценка, В. Васильєвої. Проте правовий статус простого акціонерного товариства в Республіці Польща не був предметом наукових досліджень в Україні.

Постановка завдання. Метою статті є дослідження особливостей правового статусу простого акціонерного товариства у Республіці Польща; виявлення найбільш прогресивного та позитивного досвіду польського законодавця з метою його вивчення та обгрунтування можливого подальшого впровадження у законодавство України. 
Результати дослідження. Н.А. Саніахметова вказує, що організаційно-правова форма $є$ визначальною для характеристики об'єкта прав, обов'язків, меж відповідальності конкретного суб'єкта підприємницької діяльності [3, с. 185-186].

Д.В. Задихайло, акцентуючи увагу на організаційно-правовій формі, також зазначає, що це поняття $є$ виключно важливим, тому що $є$ комплексною правовою характеристикою відносин, які виникають 3 приводу створення, функціонування і ліквідації суб' єкта підприємницької діяльності (юридичної особи), у тому числі включає в себе такі параметри як характер взаємовідносин між засновниками у процесі створення організації і управління нею, правовий режим майна, закріпленого за організацією фонду, характер майнової відповідальності засновників за зобов'язаннями заснованої ними організації [4].

На думку I.М. Кучеренко організаційно-правова форма дає підставу вирізняти юридичну особу як особливий вид юридичної особи. Іншими словами, це певна сукупність ознак, визначених у законах, включаючи й ті ознаки, які не є характерними тільки для конкретної організаційно-правової форми, але дають загальне уявлення про певний вид юридичної особи як єдине ціле [5, c. 291].

I.Ф. Коваль зазначає, що організаційна-правова форма становить свого роду конституцію, модель, основу, на підставі якої здійснюється господарська діяльність суб'єкту господарювання. Задля ефективного ведення господарської діяльності суб' єктам господарювання, зокрема господарським організаціям, важливо чітко визначитися із вибором своєї організаційно-правової форми, оскільки від такого вибору залежить порядок створення, функціонування, реорганізації та ліквідації [6].

Як зазначають фахівці, внаслідок об’єктивних чинників дослідження у цій галузі не можуть бути вичерпними і мають гуртуватися на постійному моніторингу стану цих відносин, прогнозуванні їх розвитку, а також ретроспективному переоцінюванні і моделюванні оптимальних правових форм на цьому етапі розвитку економіки [1, с. 107].

Порівняльно-правовий аналіз сучасного стану розвитку інституту комерційних юридичних осіб та їх організаційно-правових форм в Україні та деяких інших країнах світу (Німеччині, Франції, Англії, США, Японії, КНР) свідчить про наявність двох тенденцій: з одного боку - існування в багатьох країнах світу базового спектра організаційно-правових форм (повні і командитні товариства, товариство з обмеженою відповідальністю, товариство 3 додатковою відповідальністю, акціонерне товариство), хоча їх законодавче регулювання все ж є різним, з іншого боку - на основі базових організаційних форм з'являються їх спеціальні варіанти (комерційний банк, страхова компанія, інститути спільного інвестування тощо) [7, с. 172].

Ведучи мову про організаційно-правові форми суб'єктів підприємницької діяльності за законодавством Республіки Польща, слід вказати, що основними з них є торгові (комерційні) товариства. Види торгових (комерційних) товариств, порядок і мету їх створення, внутрішню організацію, порядок та способи формування майна торгових (комерційних) товариств, питання їх відповідальності за зобов'язаннями, а також питання реорганізації та ліквідації товариств у Республіці Польща визначає Кодекс торгових товариств від 15 вересня 2000 року [8], крім простого товариства, правову основу для якого закріплено нормами Цивільного кодексу Республіки Польща від 23 квітня 1964 року [9].

Кодекс торгових товариств визначає такі види торгових (комерційних) товариств: повне товариство, партнерське товариство, командитне товариство, командитно-акціонерне товариство, акціонерне товариство та товариство з обмеженою відповідальністю (стаття 1 § Кодексу).

Всі товариства традиційно в Республіці Польща поділяють на дві групи:

1) особові товариства - повне товариство, партнерське товариство, командитне товариство, командитно-акціонерне товариство, просте товариство);

2) капітальні товариства - товариство з обмеженою відповідальністю та акціонерне товариство.

При класифікації товариств на товариства особові і товариства капітальні вирішальними є критерії наявності або відсутності прав юридичної особи та відповідальності перед третіми особами за зобов'язаннями, тобто або відповідають учасники (особи), або товариство як окремий суб'єкт права $[10 ; 6]$.

Законодавче регламентування організаційно-правових форм суб'єктів підприємницької діяльності (торгових товариств) у Республіці Польща має свої традиції, є відносно сталим і фактично було незмінним у частині видів товариств із 1934 року. Слід врахувати, що Республіка Польща 32004 року є членом ЄС. Однак, як зазначає Я.С. Марущак, гармонізація законодавства ЄС у сфері права компаній ніколи не мала на меті уніфікувати систему організаційно-правових 
форм юридичних осіб у державах-членах ЄС. У зв’язку з цим у договорі про функціонування ЄС у найбільш загальному вигляді визначено поняття «товариство», залишаючи питання конкретних організаційно-правових форм, у яких може створюватися таке товариство, та наділення їх ознаками правосуб'єктності на розсуд національних законодавчих органів [11, с. 125].

30 серпня 2019 року до Кодексу торгових товариств від 15 вересня 2000 року відповідним законом внесено зміни, якими запроваджено нову організаційно-правовому форму для здійснення підприємницької діяльності, а саме просте акціонерне товариство ${ }^{1}$. Зміни набудуть чинності з 01 березня 2020 року [12].

Мотивом для ініціювання питання про необхідність впровадження нового виду капітального товариства в правову систему Республіки Польща було дослідження правового середовища реалізації StartUp-проєктів, які найчастіше реалізуються в галузі нових технологій, в умовах високої невизначеності ринку, перебуваючи на стадії пошуку оптимальної бізнес-моделі суб'єкта підприємництва.

За підрахунками ініціатора законопроєкту у Республіці Польща існує 2,7 тисяч осіб, для яких обробка інформації та похідні технології є ключовим елементом діяльності. Якщо припустити, що StartUp-и не обмежуються лише IT-індустрією, то фактична їх кількість значно більша. Разом із цим StartUp-середовище вказує на низку проблем, які обмежують розвиток таких суб'єктів підприємництва. Зокрема йдеться про труднощі із започаткуванням підприємництва, залученням капіталу або ліквідацією товариства [13].

Суб’єкти підприємництва у Республіці Польща, які мають намір реалізувати StartUp-и, змушені обирати між двома доступними видами організаційно-правих форм, які дають змогу обмежити відповідальність підприємця: товариством з обмеженою відповідальністю та акціонерним товариством. Однак, зважаючи на обмеженість ресурсів на початкових етапах запровадження підприємницької діяльності StartUp-iв, ці форми не в повністю забезпечують достатній рівень інвестицій у таке підприємництво, що в свою чергу стає непропорційним бар'єром для реалізації проєкту. Тому жодна 3 організаційно-правових форм, визначена чинним законодавством Республіки Польща, повністю не забезпечує належну правову регламентацію підприємництва щодо реалізації інноваційних проєктів.

Потенціал StartsUp-ів у 2023 році згідно з прогнозами Deloitte складе 2,2 мільярда злотих доданої вартості, понад 50 тисяч робочих місць та 757 мільйонів злотих доходів для домашніх господарств [14].

Отже, просте акціонерне товариство створене як засіб для стимулювання інвестування в інноваційну діяльність та нові технології, що забезпечать гнучкість, необхідну для використання електронних та цифрових засобів зв'язку на кожному етапі роботи товариства. $€$ всі підстави вважати, що просте акціонерне товариство виявиться більш придатним, ніж товариство 3 обмеженою відповідальністю для ведення всіх видів підприємницької діяльності, крім діяльності великих суб'єктів підприємництва, які підпадають під дію спеціальних галузевих норм.

Фактично, просте акціонерне товариство є поєднанням найбільш позитивних ознак, характеристик та елементів товариства з обмеженою відповідальністю та акціонерного товариства, що дасть змогу повністю реалізувати StartUp та інші інноваційні рішення суб'єктів підприємництва.

Основними особливостями простого акціонерного товариства є:

- відсутність бар'єрів для створення товариства (стартовий капітал складає 1 злотий). Акції простого акціонерного товариства не матимуть номінальної вартості, у статутний капітал товариства може бути внесено невідчужуване право або безпосереднє виконання певної роботи. Наведене дозволить надати статус акціонера особам, які вносять до товариства лише знання та навички, що виключає обов'язковість проведення оцінки вкладу на стадії започаткування підприємницької діяльності;

- швидка процедура електронної реєстрація (за 24 години за допомогою форми разом із можливістю реєстрації за допомогою «традиційного» методу);

- спрощення та діджиталізація процедури управління товариством (включаючи можливість прийняття рішень через електронну пошту чи відеоконференцію);

- свобода та гнучкість у визначенні видів акцій та принципів діяльності товариства;

- просте управління активами товариства та відсутність «замороженого» акціонерного капіталу. В той же час на товариство покладається зобов'язання забезпечувати платоспроможність і вживати інших заходів, що забезпечують захист кредиторів;

${ }^{1}$ Польською мовою Prosta Spółka Akcyjna. 
- спрощений електронний реєстр акціонерів, який може вести інвестиційна компанія або нотаріус. Крім того, існують погляди, що така організаційно правова форма як просте акціонерне товариство уможливить використовувати блокчейну для ведення реєстру акціонерів;

- відсутність статусу публічного товариства (акції простого акціонерного товариства не будуть розміщуватися на біржі). Проте товариство не позбавлено можливості набути статус публічного товариства в спосіб реорганізації в акціонерне товариство;

- проста та гнучка структура органів управління (відсутність обов'язку створювати наглядову раду та можливість призначення ради директорів);

- спрощена процедура ліквідації товариства - час, необхідний для проведення ліквідації, скорочено порівняно з іншими товариствами (становить 3 місяці). Крім того, передбачено можливість ліквідації товариства шляхом набуття iï активів і пасивів одним акціонером.

Вказані вище положення будуть викладені у статтях 300-1-300-134 Глави 1А «Просте акційне товариство» Кодексу торгових товариств Республіки Польща.

Слід звернути увагу, що поряд зі схвальними відгуками щодо впровадження організаційно-правової форми простого акціонерного товариства від представників підприємництва існують думки щодо помилковості прийнятих рішень. Зокрема, професор А. Кідиба вважає, що це абсолютно непотрібна конструкція, яка порушує всю систему корпоративного права та містить багато помилок. «Ніхто не стверджує, що не варто намагатися вносити зміни, але ви можете зробити це досить просто, змінивши норми щодо товариства з обмеженою відповідальністю», зазначає науковець.

Піддається критиці і обсяг нормативного акту, який сягає майже стільки, скільки всі норми, що стосуються акціонерних товариств і товариств із обмеженою відповідальністю. Це свідчить, що це буде не просте, а навпаки дуже складне товариство [15]. Однак ініціатор змін до кодексу не погоджується з таким аргументом та зазначає, що на цей час товариство з обмеженою відповідальністю є найпопулярнішою формою підприємницької діяльності, а внесення суттєвих змін у його структуру та принципи діяльності означатиме проведення операцій із живим організмом. Як результат - понад 450 тисячам товариств доведеться адаптуватися до нових правил [16].

Порівняно з Республікою Польща Україна має досить обмежений перелік видів організаційно-правових форм і тому на виникаючі виклики економічного розвитку здебільшого відповідає спробами модернізувати існуючі форми, що не завжди є вдалим чи доцільним. Наприклад, на думку низки фахівців скасування нормативних вимог до величини статутного капіталу для товариств з обмеженою відповідальністю провокує власників бізнесу до розпилення капіталу, його виводу в тіньовий обіг і спекулятивні операції $[17$, с. 6]. Дискусійною є також практична доцільність відмови від обмежень щодо максимуму учасників товариства 3 обмеженою відповідальністю.

Слід також зазначити, що частина перша статті 83 ЦК України передбачає, що юридичні особи можуть створюватися як у формі товариств, установ, так в інших формах, встановлених законом. Одночасно частина перша статті 84 ЦК України містить обмеження саме щодо товариств, які здійснюють підприємницьку діяльність із метою одержання прибутку та подальшого його розподілу між учасниками (підприємницькі товариства). Вони можуть бути створені лише як господарські товариства (повне товариство, командитне товариство, товариство з обмеженою або додатковою відповідальністю, акціонерне товариство) або виробничі кооперативи.

Однак використання організаційно-правових форм, які передбачені чинним законодавством України, не повністю забезпечують потреби потенційних суб'єктів підприємницької діяльності, а адаптація існуючих форм не завжди можлива без шкоди для тих суб'єктів, які їх використовують. Їх правове регулювання не завжди забезпечує потреби суб'єктів, які мають намір реалізувати інноваційні бізнес-проєкти. Загалом же сучасні економічні відносини потребують впровадження більш гнучких форм управління, розподілу прибутку тощо.

Висновки. Чи буде вдалим досвід впровадження простого акціонерного товариства в Республіці Польща покаже час, однак в будь-якому випадку підходи польського законодавця щодо запровадження нової організаційно-правової форми підприємницької діяльності, призначеної для суб'єктів підприємницької діяльності - початківців, які мають намір реалізувати StartUp проєкти, $є$ цікавим, оскільки може мати позитивний ефект для інноваційного розвитку підприємництва у цій державі та дати приклад іншим країнам.

На перспективу слід детально вивчати можливість впровадження нових організаційно-правових форм, які в повністю забезпечать потреби для цілей ведення інноваційної підприємницької діяльності. Але вже сьогодні окремі елементи правового регулювання статусу простих акціонерних товариств можуть бути використані у процесі вдосконалення корпоративного зако- 
нодавства України. Так, важливим є вивчення досвіду щодо діджиталізації процедури управління товариством. Наприклад, Закон України «Про акціонерні товариства» [18] дозволяє проводити голосування на загальних зборах тільки шляхом заочного голосування (опитування) (частина перша статті 43 вказаного Закону), що не забезпечує як приватності голосування, так і належного контролю учасника над коректністю врахування його голосу та свідчить про суттєве відставання України від світових тенденцій щодо впровадження процесу блокчейн-голосування на зборах акціонерів компаній.

Тому особливо цінним може бути досвід Республіки Польща щодо можливості використання блокчейну для ведення реєстру акціонерів у товаристві, спрощення та пришвидшення процедури ліквідації товариства, а також можливість ліквідації товариства шляхом набуття іiї активів і пасивів одним акціонером.

\section{Список використаних джерел:}

1. Кочергіна К.О. Організаційно-правові форми господарських товариств у контексті розвитку економічних відносин. Вісник Національної юридичної академії Украӥни імені Ярослава Мудрого. Харків, 2010. № 2. С. 105-116.

2. Борисова В.І. Організаційно-правові форми юридичних осіб приватного права. Державне будівництво та місиеве самоврядування. Харків, 2004. Вип. 7. С. 91-103.

3. Саніахметова Н.А. Підприємницьке право: Суб'єкти підприємництва. Кредитування. Оренда. Лізинг. Зовнішньоекономічна діяльність. Інвестиції. Антимонопольне законодавство. Захист від недобросовісної конкуренції. Реклама : Навчальний посібник. Київ : «А.С.К.», 2001. 704 с.

4. Господарське право : підручник / Д.В. Задихайло, В.М. Пашков, Р.П. Бойчук та ін. Харків : Право, 2012., 696 c. URL: https://www.twirpx.com/file/1268812 (дата звернення: 10.12.2019).

5. Кучеренко I.М. Організаційно-правові форми юридичних осіб приватного права. ІДіП. Київ : ДП Юридичне видавництво «Аста», 2004. 328 с.

6. Коваль І.Ф., Щербакова Н.В. Щодо застосування поняття «організаційно-правова форма» у Господарському кодексі України. Форум права. 2015. № 3. С. 107-112.

7. Гейнц Р.М. Організаційно-правові форми юридичних осіб-суб'єктів підприємництва. Наукові вісті Галицької академії. Збірник наукових статей, 2008. № 2(14). С. 171-175.

8. Ustawa z 15.9.2000 r. - Kodeks spolek handlowych. URL: http://isap.sejm.gov.pl/ DetailsServlet?id= WDU20000941037 (дата звернення: 17.12.2019).

9. Ustawa z dnia 23 kwietnia 1964 r. - Kodeks cywilny Polski. URL: http://prawo.sejm.gov.pl/ isap.nsf/DocDetails.xsp?id=WDU19640160093 (дата звернення: 20.12.2019).

10. Яценко I.C. Корпоративне право Республіки Польща (основні положення) : наук.-практ. посіб. Київ : Юрінком Інтер, 2008. 232 с.

11. Марущак Я.С. Корпоративні права та обов'язки за законодавством України та Європейського Союзу : дис. канд. юрид. наук: 12.00.03 / Нац. ун-т «Одеська юрид. акад.» Одеса, 2018. $193 \mathrm{c}$.

12. Ustawazdnia30 sierpnia2019r. ozmianie ustawy-Kodeks spółek handlowych orazniektórych innych ustaw. URL: http://prawo.sejm.gov.pl/isap.nsf/DocDetails.xsp?id=WDU20190001798 (дата звернення: 20.12.2019).

13. Projekt ustawy o zmianie ustawy - Kodeks spolek handlowych oraz-niektoryc innych URL: https://bip.kprm.gov.pl/kpr/form/r62060497313,Projekt-ustawy-o-zmianie-ustawy-Kodeksspolek-handlowych-oraz-niektorych-innych-.html (дата звернення: 29.11.2019).

14. Ustawa wprowadzająca Prostą Spółkę Akcyjną - ostatnią z pakietu "100 zmian dla firm". Prezydent podpisal dokument. Gazetaprawna.pl. URL: https://biznes.gazetaprawna.pl/artykuly/ 1424646, ustawa-prosta-spolka-akcyjna-100-zmian-dla-firm.html (дата звернення: 24.12.2019).

15. Prof. Kidyba: projekt zły, a uproszczona spółka akcyjna niepotrzebna. Prawo.pl. URL: https://www.prawo.pl/prawnicy-sady/prof-kidyba-projekt-zly-a-uproszczona-spolka-akcyjna-niepotrzebna, $74835 . h t m l$.

16. Prezydent podpisał ustawę o prostej spółce akcyjnej. Prawo.pl. URL: https://www.prawo.pl/ biznes/prosta-spolka-akcyjna-prezydent-podpisal-ustawe,448144.html.

17. Дерун А.М. Раціоналізація організаційних форм господарювання в національній економіці : дис. канд юрид наук: 08.00.03 / Інститут підготовки кадрів державної служби зайнятості України. Київ, 2018. 207 с.

18. Про акціонерні товариства : Закон України від 17 вересня 2008 р. № 514-VI. Відомості Верховної Ради України. 2008. № 50-51. Ст. 384. 